\title{
Screening for Phenylketonuria (PKU): US Preventive Services Task Force Reaffirmation Recommendation
}

\author{
US Preventive Services Task Force
}

Ann Fam Med 2008;6:166. DOI: 10.1370/afm.820.

\section{RECOMMENDATION}

$\mathrm{T}$ he US Preventive Services Task Force (USPSTF) recommends screening for phenylketonuria (PKU) in newborns. (This is a grade " $\mathrm{A}$ " recommendation.) This reaffirmation recommendation statement is based on a targeted literature search for new and substantial evidence and is available onlineonly at http://www.annfammed.org/cgi/content/ full/6/2/166/DC1. Supporting evidence is available at http://www.ahrq.gov/clinic/uspstf/uspsspku.htm.

To read or post commentaries in response to this article, see it online at http://www.annfammed.org/cgi/content/full/6/2/166.

\section{Screening for Congenital Hypothyroidism: US Preventive Services Task Force Reaffirmation Recommendation}

\author{
US Preventive Services Task Force
}

Ann Fam Med 2008;6:166. DOI: 10.1370/afm.823.

\section{RECOMMENDATION}

$\mathrm{T}$ Ue US Preventive Services Task Force (USPSTF) recommends screening for congenital hypothyroidism in newborns. (This is a grade " $\mathrm{A}$ " recommendation.) This reaffirmation recommendation statement is based on a targeted literature search for new and substantial evidence and is available online-only at http:// www.annfammed.org/cgi/content/full/6/2/166a/DC1. Supporting evidence is available at http:// www.ahrq.gov/clinic/uspstf/uspscghy.htm.

To read or post commentaries in response to this article, see it online at http://www.annfammed.org/cgi/content/full/6/2/166. 